

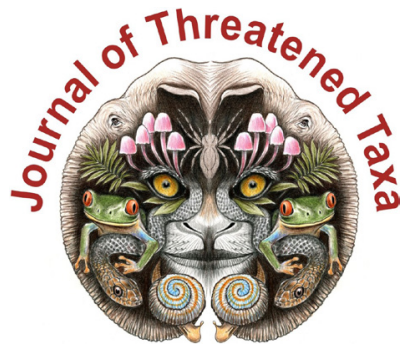

ISSN 0974-7907 (Online); ISSN $0974-7893$ (Print)

Publisher

Host

Wildlife Information Liaison Development Society

www.wild.zooreach.org

Zoo Outreach Organization www.zooreach.org

No. 12, Thiruvannamalai Nagar, Saravanampatti - Kalapatti Road, Saravanampatti, Coimbatore, Tamil Nadu 641035, India

Ph: +91 9385339863 | www.threatenedtaxa.org

Email: sanjay@threatenedtaxa.org

EDITORS

\section{Founder \& Chief Editor}

Dr. Sanjay Molur

Wildlife Information Liaison Development (WILD) Society \& Zoo Outreach Organization (ZOO),

12 Thiruvannamalai Nagar, Saravanampatti, Coimbatore, Tamil Nadu 641035, India

\section{Deputy Chief Editor}

Dr. Neelesh Dahanukar

Noida, Uttar Pradesh, India

\section{Managing Editor}

Mr. B. Ravichandran, WILD/ZOO, Coimbatore, India

\section{Associate Editors}

Dr. Mandar Paingankar, Government Science College Gadchiroli, Maharashtra 442605, India

Dr. Ulrike Streicher, Wildlife Veterinarian, Eugene, Oregon, USA

Ms. Priyanka Iyer, ZOO/WILD, Coimbatore, Tamil Nadu 641035, India

Dr. B.A. Daniel, ZOO/WILD, Coimbatore, Tamil Nadu 641035, India

\section{Editorial Board}

Dr. Russel Mittermeier

Executive Vice Chair, Conservation International, Arlington, Virginia 22202, USA

\section{Prof. Mewa Singh Ph.D., FASc, FNA, FNASc, FNAPsy}

Ramanna Fellow and Life-Long Distinguished Professor, Biopsychology Laboratory, and Institute of Excellence, University of Mysore, Mysuru, Karnataka 570006, India; Honorary Professor, Jawaharlal Nehru Centre for Advanced Scientific Research, Bangalore; and Adjunct Professor, National Institute of Advanced Studies, Bangalore

\section{Stephen D. Nash}

Scientific Illustrator, Conservation International, Dept. of Anatomical Sciences, Health Sciences Center, T-8, Room 045, Stony Brook University, Stony Brook, NY 11794-8081, USA

\section{Dr. Fred Pluthero}

Toronto, Canada

\section{Dr. Priya Davidar}

Sigur Nature Trust, Chadapatti, Mavinhalla PO, Nilgiris, Tamil Nadu 643223, India

\section{Dr. Martin Fisher}

Senior Associate Professor, Battcock Centre for Experimental Astrophysics, Cavendish

Laboratory, JJ Thomson Avenue, Cambridge CB3 OHE, UK

\section{Dr. John Fellowes}

Honorary Assistant Professor, The Kadoorie Institute, 8/F, T.T. Tsui Building, The University of Hong Kong, Pokfulam Road, Hong Kong

\section{Prof. Dr. Mirco Solé}

Universidade Estadual de Santa Cruz, Departamento de Ciências Biológicas, Vice-coordenado do Programa de Pós-Graduação em Zoologia, Rodovia Ilhéus/Itabuna, Km 16 (45662-000)

Salobrinho, Ilhéus - Bahia - Brasil

\section{Dr. Rajeev Raghavan}

Professor of Taxonomy, Kerala University of Fisheries \& Ocean Studies, Kochi, Kerala, India

\section{English Editors}

Mrs. Mira Bhojwani, Pune, India

Dr. Fred Pluthero, Toronto, Canad

Mr. P. Ilangovan, Chennai, India

Web Development

Mrs. Latha G. Ravikumar, ZOO/WILD, Coimbatore, India

\section{Typesetting}

Mr. Arul Jagadish, ZOO, Coimbatore, India

Mrs. Radhika, ZOO, Coimbatore, India

Mrs. Geetha, ZOO, Coimbatore India
Fundraising/Communications

Mrs. Payal B. Molur, Coimbatore, India

Subject Editors 2018-2020

Fungi

Dr. B. Shivaraju, Bengaluru, Karnataka, India

Dr. R.K. Verma, Tropical Forest Research Institute, Jabalpur, India

Dr. Vatsavaya S. Raju, Kakatiay University, Warangal, Andhra Pradesh, India

Dr. M. Krishnappa, Jnana Sahyadri, Kuvempu University, Shimoga, Karnataka, India

Dr. K.R. Sridhar, Mangalore University, Mangalagangotri, Mangalore, Karnataka, India

Dr. Gunjan Biswas, Vidyasagar University, Midnapore, West Bengal, India

\section{Plants}

Dr. G.P. Sinha, Botanical Survey of India, Allahabad, India

Dr. N.P. Balakrishnan, Ret. Joint Director, BSI, Coimbatore, India

Dr. Shonil Bhagwat, Open University and University of Oxford, UK

Prof. D.J. Bhat, Retd. Professor, Goa University, Goa, India

Dr. Ferdinando Boero, Università del Salento, Lecce, Italy

Dr. Dale R. Calder, Royal Ontaro Museum, Toronto, Ontario, Canada

Dr. Cleofas Cervancia, Univ. of Philippines Los Baños College Laguna, Philippines

Dr. F.B. Vincent Florens, University of Mauritius, Mauritius

Dr. Merlin Franco, Curtin University, Malaysia

Dr. V. Irudayaraj, St. Xavier's College, Palayamkottai, Tamil Nadu, India

Dr. B.S. Kholia, Botanical Survey of India, Gangtok, Sikkim, India

Dr. Pankaj Kumar, Kadoorie Farm and Botanic Garden Corporation, Hong Kong S.A.R., China

Dr. V. Sampath Kumar, Botanical Survey of India, Howrah, West Bengal, India

Dr. A.J. Solomon Raju, Andhra University, Visakhapatnam, India

Dr. Vijayasankar Raman, University of Mississippi, USA

Dr. B. Ravi Prasad Rao, Sri Krishnadevaraya University, Anantpur, India

Dr. K. Ravikumar, FRLHT, Bengaluru, Karnataka, India

Dr. Aparna Watve, Pune, Maharashtra, India

Dr. Qiang Liu, Xishuangbanna Tropical Botanical Garden, Yunnan, China

Dr. Noor Azhar Mohamed Shazili, Universiti Malaysia Terengganu, Kuala Terengganu, Malaysia

Dr. M.K. Vasudeva Rao, Shiv Ranjani Housing Society, Pune, Maharashtra, India

Prof. A.J. Solomon Raju, Andhra University, Visakhapatnam, India

Dr. Mandar Datar, Agharkar Research Institute, Pune, Maharashtra, India

Dr. M.K. Janarthanam, Goa University, Goa, India

Dr. K. Karthigeyan, Botanical Survey of India, India

Dr. Errol Vela, University of Montpellier, Montpellier, France

Dr. P. Lakshminarasimhan, Botanical Survey of India, Howrah, India

Dr. Larry R. Noblick, Montgomery Botanical Center, Miami, USA

Dr. K. Haridasan, Pallavur, Palakkad District, Kerala, India

Dr. Analinda Manila-Fajard, University of the Philippines Los Banos, Laguna, Philippines

Dr. P.A. Sinu, Central University of Kerala, Kasaragod, Kerala, India

Dr. Afroz Alam, Banasthali Vidyapith (accredited A grade by NAAC), Rajasthan, India

Dr. K.P. Rajesh, Zamorin's Guruvayurappan College, GA College PO, Kozhikode, Kerala, India

Dr. David E. Boufford, Harvard University Herbaria, Cambridge, MA 02138-2020, USA

Dr. Ritesh Kumar Choudhary, Agharkar Research Institute, Pune, Maharashtra, India

Dr. Navendu Page, Wildlife Institute of India, Chandrabani, Dehradun, Uttarakhand, India

\section{Invertebrates}

Dr. R.K. Avasthi, Rohtak University, Haryana, India

Dr. D.B. Bastawade, Maharashtra, India

Dr. Partha Pratim Bhattacharjee, Tripura University, Suryamaninagar, India

Dr. Kailash Chandra, Zoological Survey of India, Jabalpur, Madhya Pradesh, India

Dr. Ansie Dippenaar-Schoeman, University of Pretoria, Queenswood, South Africa

Dr. Rory Dow, National Museum of natural History Naturalis, The Netherlands

Dr. Brian Fisher, California Academy of Sciences, USA

Dr. Richard Gallon, llandudno, North Wales, LL30 1UP

Dr. Hemant V. Ghate, Modern College, Pune, India

Dr. M. Monwar Hossain, Jahangirnagar University, Dhaka, Bangladesh

Mr. Jatishwor Singh Irungbam, Biology Centre CAS, Branišovská, Czech Republic.

Dr. Ian J. Kitching, Natural History Museum, Cromwell Road, UK

Dr. George Mathew, Kerala Forest Research Institute, Peechi, India

For Focus, Scope, Aims, and Policies, visit https://threatenedtaxa.org/index.php/JoTT/aims_scope
For Article Submission Guidelines, visit https://threatenedtaxa.org/index.php/JoTT/about/submissions
For Policies against Scientific Misconduct, visit https://threatenedtaxa.org/index.php/JoTT/policies_various

continued on the back inside cover 


\title{
Reproductive biology of Ophiorrhiza caudata C.E.C.Fisch. (Rubiaceae), an endemic and endangered creeping perennial herb of the Western Ghats, India
}

\author{
Maria Theresa ${ }^{1}$ (D), Appukuttan Kamalabai Sreekala ${ }^{2}$ (D) \& Jayalakshmi Mohanlal ${ }^{3}$ (D) \\ ${ }^{1-3}$ Division of Conservation Biology, Jawaharlal Nehru Tropical Botanic Garden and Research Institute, Pacha-Palode, \\ Thiruvananthapuram, Kerala 695562, India. \\ ${ }^{1}$ mariavempally@gmail.com, ${ }^{2}$ ak.sreekala@gmail.com (corresponding author), ${ }^{3}$ jeevaa88@gmail.com
}

\begin{abstract}
Ophiorrhiza caudata is a creeping, perennial herb distributed along wet and shady areas. The species is distylous with two distinct floral morphs: pin and thrum. Flowering usually occurs during the monsoon season. No particular difference was noticed in the flowering phenology of the two morphs. Presently the species is self-incompatible, however, it shows a tendency towards intramorph compatibility. Fruit set is above $60 \%$ in open pollination and intermorph pollination. Bees and butterflies are the major pollinators. The pollen flow between the two floral morphs varies depending upon floral morphology and pollinators. Fruit is a bi-valved capsule which dehisces by a splashing drop mechanism. The seeds are very minute. The rate of seed germination and seedling establishment in the wild condition is very poor due to adverse climatic factors. Ophiorrhiza caudata is struggling for survival in its natural habitat, where habitat fragmentation, climatic factors and poor seedling establishment could account for its narrow distribution.
\end{abstract}

Keywords: Floral morphs, flowering phenology, perennial herb, pollination, seed germination.

Editor: Cleofas Cervancia, University of Philippines Los Bayos College Laguna, Philippines.

Date of publication: 26 November 2021 (online \& print)

Citation: Theresa, M., A.K. Sreekala \& J. Mohanlal (2021). Reproductive biology of Ophiorrhiza caudata C.E.C.Fisch. (Rubiaceae), an endemic and endangered creeping perennial herb of the Western Ghats, India. Journal of Threatened Taxa 13(13): 20056-20065. https://doi.org/10.11609/jott.6741.13.13.20056-20065

Copyright: (c) Theresa et al. 2021. Creative Commons Attribution 4.0 International License. JoTT allows unrestricted use, reproduction, and distribution of this article in any medium by providing adequate credit to the author(s) and the source of publication.

Funding: University of Kerala.

Competing interests: The authors declare no competing interests.

Author details: DR. MARIA THERESA has been awarded PhD by the University of Kerala. She joined as assistant professor (on contract) in the department of botany, Newman College, Thodupuzha, Idukki. DR. A.K. SREEKALA is working as Principal scientist in the division of conservation biology, JNTBGRI, Palode. She has published more than 85 research papers in national and international journals. Also presented 60 research papers in national and international conferances. Dr. JAYALAKSHMI MOHANLAL has been awarded PhD by the University of Kerala and presently she is working as guest lecturer in the department of botany, Vimala College (Autonomous), Thrissur.

Author contributions: All the three authors contributed equally for the study as well as MS preparation.

Acknowledgements: The authors are thankful to the Director, KSCSTE-Jawaharlal Nehru Tropical Botanic Garden and Research Institute for providing facilities and the Department of Forests and Wildlife, Government of Kerala, special thanks to conduct study in the forest area. The authors are thankful to the manuscript reviewers. The first author is thankful to the University of Kerala, Thiruvananthapuram for providing Junior Research Fellowship.
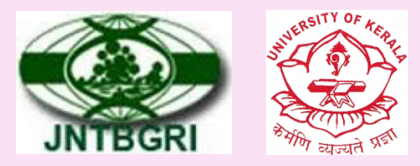


\section{INTRODUCTION}

The genus Ophiorrhiza L. (Rubiaceae) is believed to be Indo-Malaysian in origin (Mabberly 2008), and different species are scattered throughout tropicalsubtropical Asia, New Guinea, Australia, and the Pacific islands. The roots of these herbaceous plants were used against snake venom from ancient times, and various plant parts are characterised by the presence of the alkaloid camptothecin and its derivatives (Yamazaki et al. 2003). Camptothecin is an inhibitor of the enzyme topoisomerase-1 (Uday \& Kondapi 2010) and has anticancerous properties. Some Ophiorrhiza species such as $O$. barnesii, $O$. brunonis and $O$. incarnata are also under threat of extinction due to climatic change, habitat disturbance, natural calamities and obstruction to pollination mechanisms and reproduction.

The genus has been considered as distylous (Deb \& Mondal 1977) with two floral morphs: pin (long-styled) and thrum (short-styled). Distyly is usually associated with self-incompatibility, that is, the flower of one morph cannot be fertilized by the pollen from the same flower or from another flower of same morph. This kind of heteromorphic incompatibility is reported from 25 plant families including Rubiaceae (Ganders 1979; Lloyd \& Webb 1992). Darwin (1877) considered distyly as an adaptation to promote cross breeding. Ophiorrhiza caudata C.E.C.Fisch. is a creeping herb distributed along the wet and shady regions of southern Western Ghats. The species was considered extinct (Deb \& Mondal 1997), and IUCN (1997) included it under the extinct category. It was rediscovered in 2009 (Joseph \& Joseph 2009), 70 years after its last report. Considering the medicinal value and present status of this endemic distylous species, a study on its reproductive mechanism is needed for conservation. The present investigation was carried out during 2013-2016 to examine the flowering phenology, floral biology, breeding system, pollination and seed biology of $O$. caudata.

\section{MATERIALS AND METHODS}

\section{Study area}

A clumped population of $O$. caudata was located in the Mankulam and Kallar forest areas of Idukki district (Image 1a) in Kerala (10¹1.9230"N 76092.884"E, 340$2,102 \mathrm{~m}$ ). The average rainfall in the area ranges from 2,500-3,000 $\mathrm{mm}$, with $70 \%$ occurring during the southwest monsoon; mist and frost prevail during the winter months and high humidity during the monsoon season.
O. caudata is distributed along the wet and shady areas of Mankulam and Kallar (Figure 1). Ophiorrhiza mungos, $O$. barberi, and $O$. barnesii are the other ophiorrhiza species distributed along this area. Dictyospermum montanum, Neanotis decipiens, Plectanthus malabaricus, Cleome speciosa, Impatiens elegans, Impatiens maculata, Cyanotis pilosa, and Pilea melastomoides are other associated plants in the area.

\section{Phenology and floral morphology}

Twenty-five healthy individuals of approximately the same age from both floral morphs (i.e., pin and thrum) were marked, and periodic observations were made on different developmental events from the emergence of vegetative buds up to seed germination and successful establishment of seedlings. The observations were made as per the method suggested by Dafni (2007). The time of anthesis and anther dehiscence, flower colour and odour, nectar production, stigma type, and flower longevity were noticed. The flower morphology of each morph was studied with the help of hand lens and dissection microscope. Floral measurements were taken in millimetres by using a digital vernier calliper. For this purpose, 20 flowers of each morph were collected from the field, preserved in $70 \%$ ethanol and detailed study was conducted in the laboratory. This was helpful to analyse heterostyly in the species.

The mean number of pollen grains per flower was calculated by dissecting a single anther in a drop of acetocarmine: glycerine (3: 1) on a microscopic slide and counting all the grains; the number obtained was multiplied by five (the number of anthers per flower). In this way the pollen count was taken from anthers of 10 flowers (from 10 different individuals of each morph) and the mean number of pollen grains per flower was calculated. The average number of ovules per ovary was counted by dissecting young pistils under a microscope. Pollen-ovule ratio was calculated as per the method suggested by Cruden (1977).

\section{Pollination biology}

Field observations of flower visitors were carried out from 0600 to $1630 \mathrm{~h}$. Insect foraging activity was noted by visual observation. Number of floral visits per hour by each pollinator, their foraging behaviour, time spent by the insect on each flower and stigma touch were recorded. Temporal activities of the insects on pin and thrum morphs were distinctly noted.

Pollinators were trapped using insect nets, pan traps and sticky traps (Toler et al. 2005). Trapped insects were preserved individually in small screw cap vials $(10 \mathrm{ml})$ 


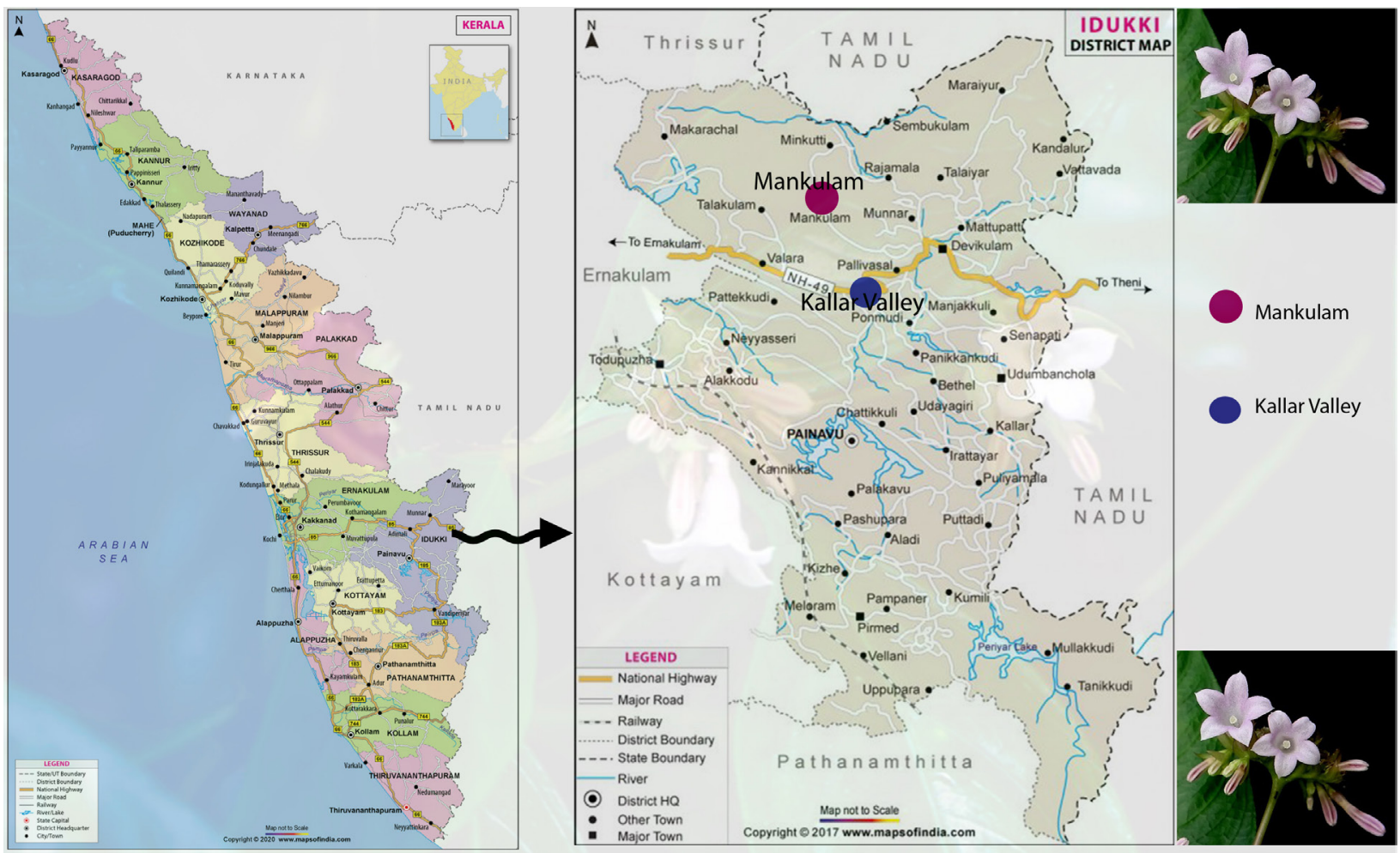

Figure 1. Study area in Idukki district-Mankulam and Kallar Valley

containing $4 \mathrm{ml}$ of ethyl alcohol. The vials were vigorously shaken for two minutes to remove pollen grains from the insect's body. The insects were taken out from the vial and the suspension was allowed to evaporate. After evaporation, pollen grains were mounted in a few drops of acetocarmine-glycerin stain and observed under a microscope. The number of stained and unstained pollen grains of the selected plant species was counted. The pollinators were identified with the help of entomologists from the school of biology, IISER, Thiruvananthapuram, and an insect manual.

\section{Breeding system}

The mating system of the distylous species was analysed by fruit set comparisons in the field after various breeding experiments such as self-pollination, intramorph pollination, intermorph pollination, emasculation \& bagging, and bagging without emasculation. Fruit set after these experiments were compared with the fruit set after open pollination. For each of the breeding experiment, 150 flowers were chosen from different individuals. The results were compared with Student's t-test. (SPSS ver.16.0 at the significance level of $\alpha=0.05$ )

Self-pollination was conducted to check whether the species is self-compatible. For this, flower buds one day before anthesis were bagged using butter paper bags and pollinated the next day using pollen from flowers of the same individual. The pollinated flowers were bagged again, and periodically observed for fruit set. For intramorph pollination, flower buds were emasculated and bagged one day before anthesis using butter paper bags. On the next day, pollen grains were transferred from flowers of other individuals of the same morph into the opened flower. For intermorph pollination, the flower buds were emasculated, bagged and were pollinated with pollen grains from flowers of the other morph. Another set of flowers were emasculated and bagged to check the occurrence of apomictic fruit test. Several flower buds were bagged without emasculation to test autogamous self-pollination within each morph.

\section{Fruit and Seed biology}

Fruit development was observed from the day of pollination until its maturation and dehiscence. Mature fruits from each morph were harvested and seeds collected. The average number of seeds developed per fruit/capsules was calculated. For analysing the reproductive success of flowers after pollination, the number of flowers per day in a $10 \times 10$ m quadrate of the population and the number of mature fruits developed from these flowers were scored and the flower-fruit 
ratio was calculated.

For the evaluation of seed dispersal, laboratory experiments were preferred because the seeds of Ophiorrhiza were minute to count from the intact soil. Peduncles with an open capsule containing mature seeds were placed in individual bottles and set on a floor covered with three square meters of white paper for easy detection of the scattered seeds. One $2 \mathrm{ml}$ syringe fixed at a height of $2 \mathrm{~m}$ and water drops were allowed to fall onto the open capsule. Each water drop was approximately $0.1 \mathrm{ml}$. After the seeds scattered by water droplets, the longest distance from the peduncle to the seed was measured. The experiments were repeated at least five times for each morph (Nakanishi 2002).

For analysing seed germination, mature fruits were covered with paper bags before dehiscence and seeds were collected from each morph separately. Seeds were stored under laboratory conditions and allowed to germinate in petri dishes under different conditions: 1) Whatman filter paper (Grade 1); 2) soil from natural habitat; 3) soil from JNTBGRI campus. Samples of seeds were also allowed to germinate in the natural habitat to assess the influence of environmental factors on seed germination. Five replicates of 30 seeds of each morph were allowed to germinate every month to determine the optimal month for seed germination and seedling establishment. Quantitative features such as the number of days taken for seed germination and percentage of seed germination and seedling establishment in the field as well as in the laboratory conditions were analyzed periodically.

\section{RESULTS}

\section{Phenology and floral morphology}

$O$. caudata is a perennial creeping herb that sprouts at the end of May. Vegetative buds arise from the nodes of creeping stems during the monsoon, and the young leaves are yellowish-green. When mature, it becomes dark green in its upper surface and brownish green in the lower surface. The plants started to bloom in June and continued to January (Figure 2). New seedlings take 75-86 days to flower. Peak blooming was noticed from mid-August to mid-September (Figure 2). When the fruit matures, each fruit contains 45-110 minute brownish seeds which are dispersed by rain water

The inflorescence of $O$. caudata is a terminal capitate cyme with 1-6 flowers, with the flowers arranged in a centrifugal manner. Flower development completes within 7-10 days (Image 1d). Anthesis was noticed in

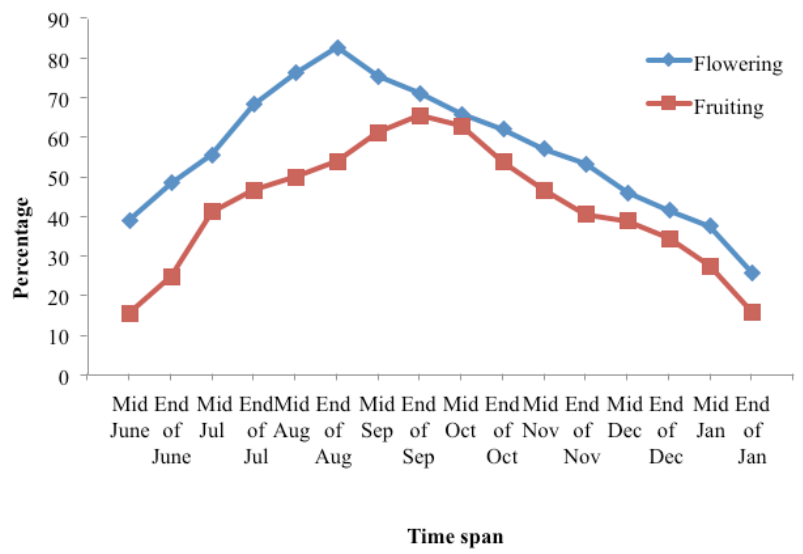

Figure 2. Flowering and fruiting phenology of Ophiorrhiza caudata.

the morning hours between 0600-0845 $\mathrm{h}$ and anther dehiscence occurs soon after flower opening. Flowers of thrum morphs open earlier than pin ones. Flowers are white with a mild fragrance and the nectar is located on the semicircular disc present above the ovary. Average life span of each flower is 20-24 hours. Blooming lasts for an average of 215 days in a year. Fruit development was completed within 25-35 days after pollination. During heavy rain, dehiscence of fruits occurs by splashing drop mechanism.

The inflorescence and peduncles are glabrous, and $2.5-3.5 \mathrm{~cm}$ long. The flowers are white, lanceolate and 9.3-13.5 mm long. Pedicels are 1-1.5 $\mathrm{mm}$ long. Hypanthium is cup shaped. Calyx lobes are 5, ovatelanceolate, acute and shortly keeled at back. Corolla is white and infundibuliform with 5 lobes. They are 8-10 $\mathrm{mm}$ long and glabrous outside with a ring of hairs on the throat of corolla tube. Stamens are 5 and are epipetalous; anthers are oblong and longitudinally dehiscent. Average length of the stamen is different in the two different morphs, $2.45 \mathrm{~mm}$ in pin flowers and $7.19 \mathrm{~mm}$ in thrum flowers. Ovary is obovoid, $0.59-0.85 \mathrm{~mm} \times 0.31-0.41$ $\mathrm{mm}$ in pin flowers and $0.65-0.81 \mathrm{~mm} \times 0.33-0.41 \mathrm{~mm}$ in thrum flowers. Style is slender in both morphs but its length varies among the two different morphs, $5.95 \mathrm{~mm}$ in pin flowers and $1.79 \mathrm{~mm}$ in thrum flowers. Stigmabifid and capitate in pin flowers and lanceolate in thrum flowers (Image 1b,c).

\section{Pollination Biology}

Butterflies, flies, bees and ants were the major floral visitors of $O$. caudata, and they were attracted by the mild fragrance of flowers. Flowering was in rainy season, and rainwater promotes pollination (Hydrophily) in O. caudata. One unidentified insect visits the flowers frequently; it spend around $45 \pm 15 \mathrm{sec}$ per flower in 


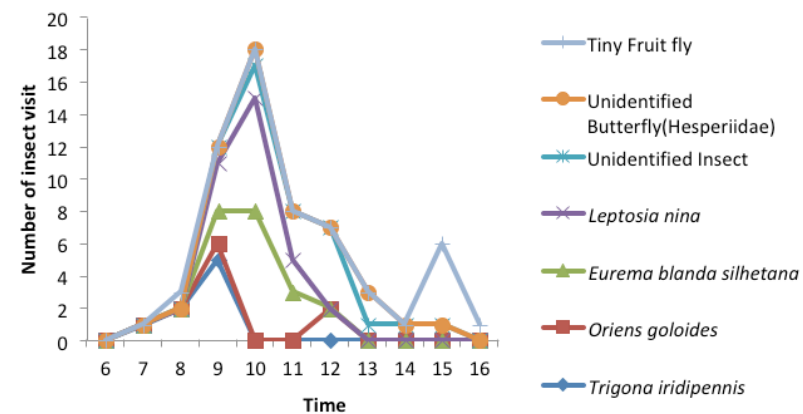

Figure 3. Foraging activity of pollinators: Ophiorrhiza caudata - pin morph.

pin morphs and $46 \pm 21 \mathrm{sec}$ per flower in thrum morphs (Figure 3,4$)$. This insect either collects pollen from the exposed anthers of thrum flowers or enters the corolla tube to collect nectar. In pin morph, they enter into the corolla tube for collecting both pollen and nectar. Pollen flow into the thrum morphs by this insect was comparatively poor because the stigma is positioned under the throat of the corolla tube and therefore there was a reduced stigma touch. The prime floral visitor was stingless bee (Trigona iridipennis). It can enter up to the throat of the corolla tube and collects both pollen and nectar. The tiny fruit flies also make irregular visits and collects nectar. Oriens goloides is a butterfly visitor with more foraging time comparing to the other butterflies. Eurema blanda silhetana and Leptosia nina are the other butterflies visiting on the same time (Figure 3, 4). However, they spend only less time per visit but have more frequent visits per flower. These tiny butterflies make frequent movements in the flower which facilitates cross-pollination. Butterflies normally rest on the corolla, exert their proboscis and collect the nectar present on the disc above the ovary. Therefore, the pollen transfer from the inserted anthers of pin morph flowers into the stigma of thrum flowers which is also located inside the corolla tube will be comparatively less.

\section{Breeding System}

Fruit set was not observed after self-pollination, emasculation and netting, netting without emasculation experiments in both the morphs. This indicated that the species was self-incompatible and there is no apomixis or parthenocarpic fruit development in this species. The percentage of fruit set after intramorph pollination in pin and thrum morphs are $6.67 \%$ and $3.33 \%$, respectively. These results indicated that $O$. caudata has a tendency towards intramorph compatibility. Pin (female) $x$ Thrum (male) and Thrum (female) $x$ Pin (male) crosses resulted in $72 \%$ and $69 \%$ fruit set respectively and no

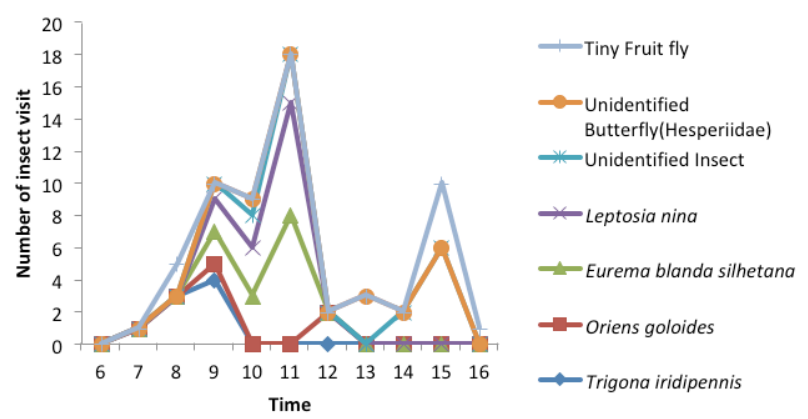

Figure 4. Foraging activity of pollinators: Ophiorrhiza caudata thrum morph.

Table 1. Percentage of fruit set in six pollination methods in pin and thrum morphs of Ophiorrhiza caudata.

\begin{tabular}{|c|c|c|c|}
\hline & Treatment & $\begin{array}{l}\text { Number } \\
\text { of flowers } \\
\text { examined }\end{array}$ & $\begin{array}{l}\text { Fruit set } \\
\text { (\%) }\end{array}$ \\
\hline \multirow[t]{3}{*}{1} & Self-pollination & & \\
\hline & Pin & 150 & 00 \\
\hline & Thrum & 150 & 00 \\
\hline \multirow[t]{3}{*}{2} & Intramorph pollination & & \\
\hline & Pin $x$ Pin & 150 & 6.67 \\
\hline & Thrum $x$ Thrum & 150 & 3.33 \\
\hline \multirow[t]{3}{*}{3} & Intermorph pollination & & \\
\hline & Pin (female) $x$ Thrum(male) & 150 & 72. 51 \\
\hline & Thrum(female) $x$ Pin(male) & 150 & 69.07 \\
\hline \multirow[t]{3}{*}{4} & Emasculation and netting & & \\
\hline & Pin & 150 & 00 \\
\hline & Thrum & 150 & 00 \\
\hline \multirow[t]{3}{*}{5} & Netting without emasculation & & \\
\hline & Pin & 150 & 00 \\
\hline & Thrum & 150 & 00 \\
\hline \multirow[t]{3}{*}{6} & Open pollination & & \\
\hline & Pin & 150 & 66.76 \\
\hline & Thrum & 150 & 64.13 \\
\hline
\end{tabular}

notable difference between the morphs $(t=3.21, P$ $>0.05$ ). Therefore, the male and female organs of both the morphs were functional. Open pollination resulted in a fruit set of $66 \%$ in pin morphs and $64 \%$ in thrum ones. Comparison of these results with the manual intermorph pollination treatments showed no notable difference (Pin (female) $x$ Thrum (male), inter-morph pollination vs. open pollination, $72 \%$ vs. $66 \%, t=4.33$, $\mathrm{P}>0.05$ and thrum (female) $\mathrm{x}$ pin (male), inter-morph pollination vs. open pollination, $69 \%$ vs. $64 \%, t=4.90, P$ $>0.05$ ) (Table 1). 


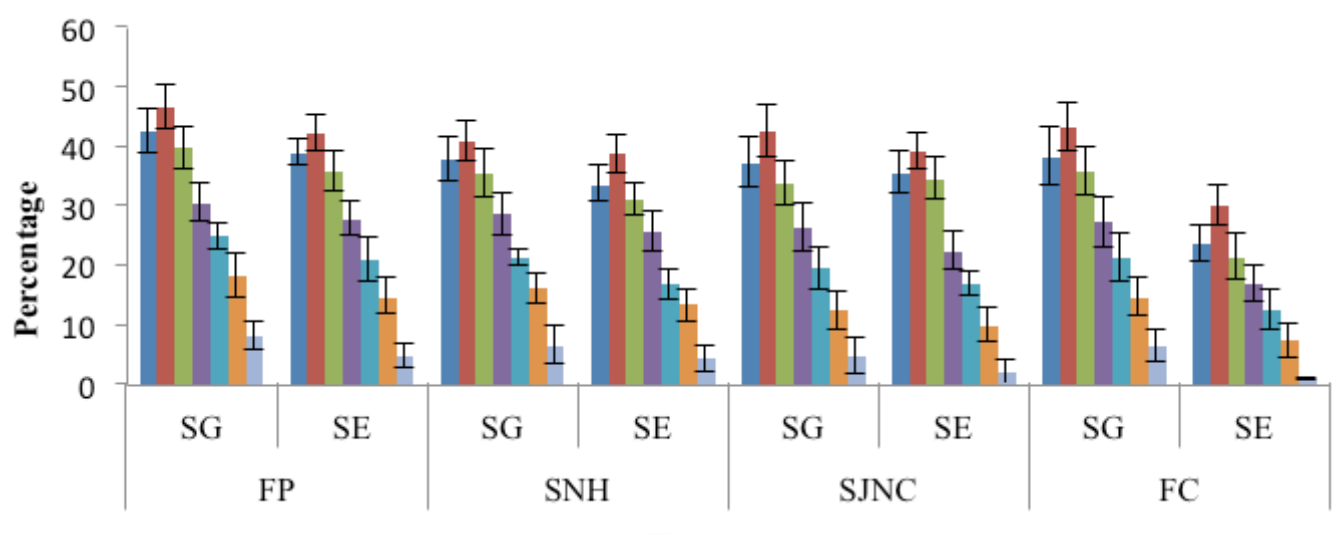

Treatments

\begin{tabular}{|c|c|c|}
\hline 0-2 weeks & 2-4 weeks & 4-8 weeks \\
\hline 10-12 weeks & 12- 14 weeks & 14-16 weeks \\
\hline
\end{tabular}

Figure 5. Seed germination of O. caudata (pin morph) at different conditions: SG-seed germination | SE-seedling establishment | FP-filter paper | SJNC-soil from JNTBGRI campus | SNH-Soil from natural habitat | FC-field condition.

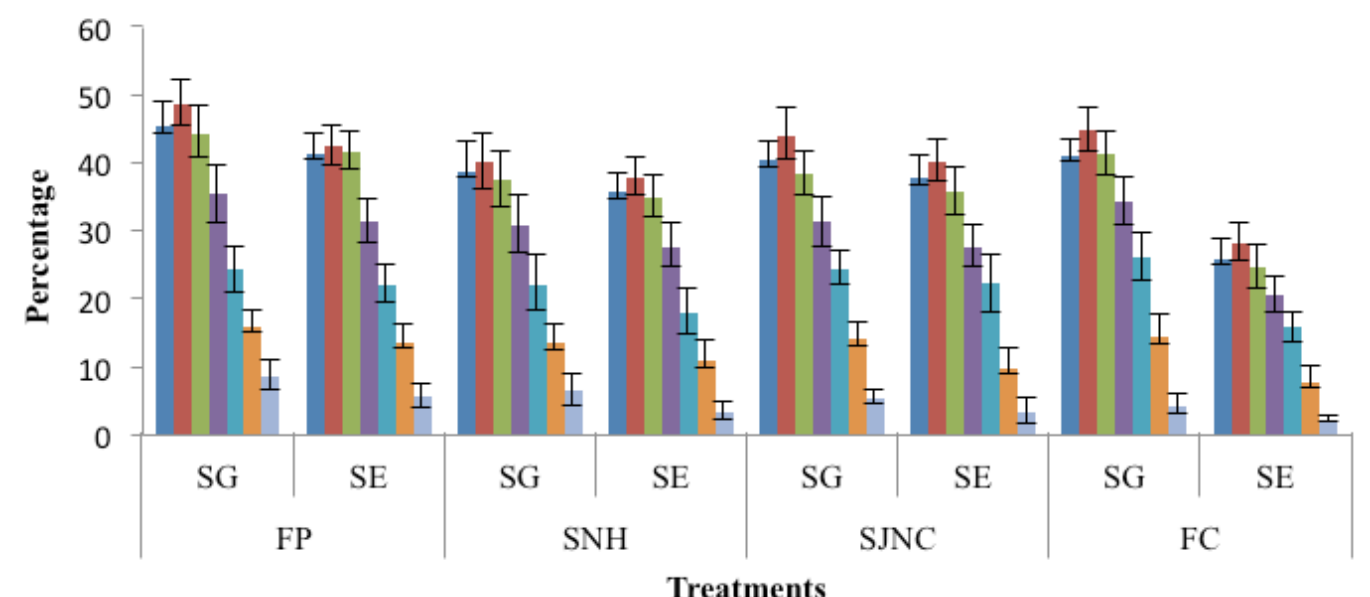

\begin{tabular}{|c|c|c|}
\hline - 0-2 weeks & 2-4 weeks & 4-8 weeks \\
\hline $10-12$ weeks & $12-14$ weeks & 14-16 weeks \\
\hline
\end{tabular}

Figure 6. Seed germination of $O$. caudata (thrum morph) at different conditions: SG-seed germination I SEseedling establishment | FP-filter paper | SJNC-soil from JNTBGRI campus I SNH-soil from natural habitat | FC-field condition.

\section{Fruit and seed biology}

The fruit is a boat-shaped, bi-valved capsule which dehisces along the dorsal surface (Image 1e). The capsule attains its maximum size $(6.7 \pm 0.51 \mathrm{~mm} \times 5.4 \pm 0.72 \mathrm{~mm}$ in pin morphs and $6.7 \pm 0.32 \mathrm{~mm} \times 5.5 \pm 0.63 \mathrm{~mm}$ in thrum morphs) within 25-35 days after pollination. Each fruit contains $86 \pm 12$ seeds in both morphs and the number of seeds in the two locules may vary. The seeds were minute $(0.68 \pm 0.06 \mathrm{~mm} \times 0.54 \pm 0.05 \mathrm{~mm}$ in pin plants and $0.64 \pm 0.07 \mathrm{~mm} \times 0.58 \pm 0.08 \mathrm{~mm}$ in thrum plants), angular, glabrous and were brown coloured. Flower-fruit ratio of pin morphs in natural condition was calculated as 1.5:1 and that of thrum flowers was 1.6:1.

\section{Seed dispersal}

The seed dispersal mechanism in 0 . caudata was splash seed dispersal by raindrops. During rain, the water drops were collected in the boat-shaped capsule containing the seeds, which are splashed out and flushed away over certain distance. Thus the raindrops provide 

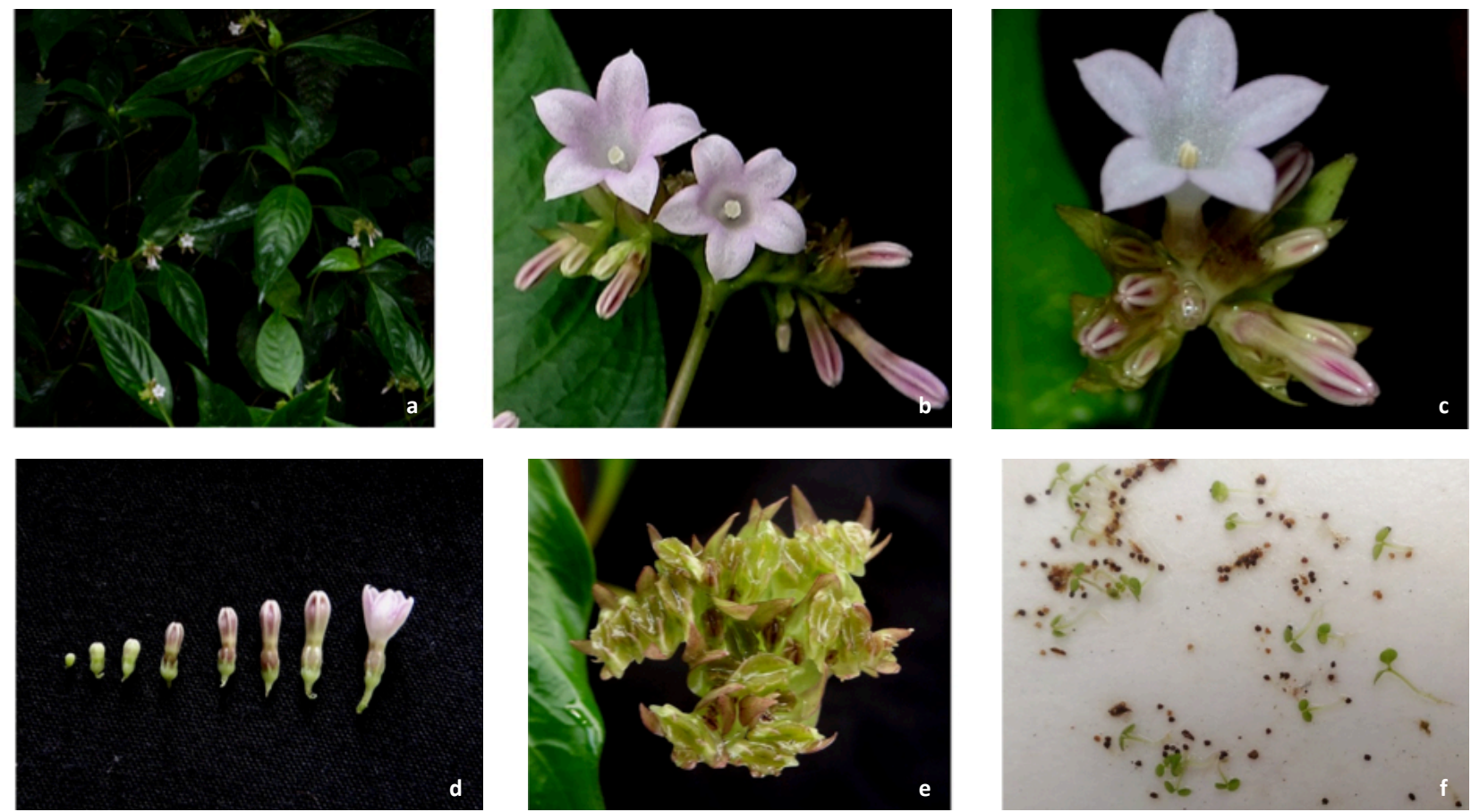

Image 1. Floral biology of Ophiorrhiza caudata C.E.C. Fisch.: a-population | b-flower of pin morph | c-flower of thrum morph | d-flower development | e-fruit | f-seed germination.

energy for the seeds to come out of the capsule. The maximum dispersal distance of seeds under laboratory conditions in pin morphs was $93 \pm 5.9 \mathrm{~cm}$ and $93 \pm 5.6$ $\mathrm{cm}$ in thrum morph seeds.

\section{Seed germination and seedling establishment}

The freshly harvested seeds of $O$. caudata shows dynamic germination in all the conditions, which indicates the seeds, are recalcitrant. Seed germination was hypogeal. In both morphs, maximum seed germination 40-45\% was noticed within 2-4 weeks after harvest (Figure 5, 6; Image 1f). The rate of germination was noticed to be declining in the next weeks. But the seedling establishment was at a reduced level while comparing to the seed germination rate in the natural habitat. This poor rate of seedling establishment may due to the heavy rain in the fruiting season. In natural condition, during heavy rain, the minute seeds are either buried in the mud or carried away by the rain water and only an average of $25 \%$ seedlings were established in the wild. However, seeds germinated in the plastic pots when transferred to the natural habitat also failed to establish due to heavy rainfall. In the natural condition, about 3\% seeds inside the capsule exhibit viviparous germination which can be considered as an adaptation for establishment of young seedlings during heavy precipitation.

\section{DISCUSSION}

The genus Ophiorrhiza L. is characterised by white or pinkish white flowers and most of the species exhibit heterostyly. Majority of the Ophiorrhiza species reported from Western Ghats exhibit the similar pattern of flowering except the varieties of $O$. brunonisis which flowers during the summer months (Deb \& Mondal 1997). Anthesis occurs in both the morphs in the early morning around $0600 \mathrm{~h}$, and all the flowers completely open within around $0845 \mathrm{~h}$. Distylous species with white tubular flowers in Rubiaceae such as Psychotria carthagenesis (Consolaro et al. 2011) follow the same pattern of anthesis. Simultaneous opening of flowers of both the morphs have a positive influence on the pollen transfer between them.

The family Rubiaceae is characterised by different pollen transfer mechanisms and functional gender of pin and thrum morphs with various pollination systems (Wolff \& Liede-Schumann 2007). Several investigations were conducted on the pollination biology of heterostylous plants in Rubiaceae, and there are species which have evolved functional dioecy in the family (Li et al. 2010). Flowering of $O$. caudata is during monsoon. The earlier studies (Wolda 1988; Fonseca et al. 2006; Silva et al. 2011) reported highest foraging activities of Hymenoptera and Lepidoptera during the rainy season. 
This observation agrees with the pollinators of candidate species, and can be considered an adaptation to suitable conditions for pollination, i.e., species tend to flower when vector availability is higher, as reported in other plant groups (Almeida \& Alves 2000; Koptur et al. 1988; Martin-Gajardo \& Morellato 2003).

The stingless bee Trigona iridipennis is a major pollinator of the selected species. Pollination by Trigona was observed in other members of Rubiaceae, including Psychotria barbiflora (Texeira \& Machado 2004) and Manettia cordifolia (Consolaro et al. 2005). They visit the flowers in morning immediately after anthesis. High level of nectar concentration in morning hours stimulated the visit of Trigona spinipes in both the morphs of Psychotria poeppigiana (Valois-Cuesta et al. 2009). In Ophiorrhiza, the nectar is present in trace amounts and was too viscous in the selected species to be measured by conventional hand refractometers. Trigona, the tiny bees can enter into the corolla tube, feed pollen and nectar from both morphs. Trigona and fruit flies can enter the narrow corolla and comes in contact with the short stigma of thrum flowers but other hymenopterans and lepidopterans are less able to enter the narrow corolla tube of thrum morphs and moreover there is a ring of hairs along the corolla tube above the stigma. If these hairs are absent, even short stigmas of thrum flowers can effectively receive pollen grains from pin flowers (Stone \& Thomson 1995) Eurema blanda silhetana and Leptosia nina are the common butterflies visiting Ophiorrhiza caudata. They usually visit the flowers after two hours of anthesis and there is a competition between them for nectar. These restless butterflies spend less time per flower but have frequent visits. Oriens goloides and an unidentified butterfly from Hesperiidae visits $O$. caudata for nectar. Butterflies usually alight near or on flowers when foraging for nectar (Naiki \& Kato 1999), and in Ophiorrhiza caudata they took the exudates secreted from the disc above the ovary by extending their proboscides into the corolla tube. Therefore, butterflies most often come in contact with the exposed floral parts from the corolla tube; anthers of thrum flowers and stigmas of pin flowers. Thus the pollen transfer from pin morphs to thrum was comparatively poor. No significant difference was observed in the foraging time, foraging period, and number of visits per flower and stigma touch among the morphs of the selected species.

According to some authors, thrum (short-styled) flowers are efficiently pollinated by insects with longer mouthparts (Beach \& Bawa 1980; Lloyd \& Webb 1992), while short-tongued insects would be more efficient pollinators of pin (long-styled) flowers (Beach \& Bawa 1980). In another view, reproductive interference might interrupt the proper functioning of disassortative pollination between short-level organs, which promote asymmetric pollen flow due to extremely narrow corollas of the species pollinated by Lepidopterans (Marten-Rodriguez et al. 2013). Ophiorrhiza caudata do not totally depend on lepidopterans for their pollination; bees, fruit flies and even rain water act as pollinating agents. Here, lepidopterans are efficient pollinators of pin morphs and asymmetry in pollen flow by insect vectors is noticed because of the narrow corolla tube. Fruit flies and Trigona can enter the narrow corolla and comes in contact with the short stigma of thrum flowers but other Hymenopterans and Lepidopterans are less able to enter the narrow corolla tube of thrum morphs. There is a ring of hairs along the corolla tube above the stigma. If these hairs are not present, even short stigmas of thrum flowers can effectively receive pollen grains from pin flowers (Stone \& Thomson 1995). Even though the pollen grains from pin flowers were attached to the proboscis of an insect, most of them would be easily swept off by the hairs in a thrum flower, which results in asymmetric pollen flow between the pin and thrum flowers (Naiki \& Kato 1999). When considering pollination by lepidopterans, some butterflies collect the nectar without the stigma touch (Naiki \& Kato 1999). However, these butterflies efficiently transfer pollen from the exposed anthers of thrum flowers to the exposed stigmas of pin flowers with their proboscis and other mouthparts or with legs and wings.

Manual pollination treatments confirmed that the species is self-incompatible and no fruits are developed by apomixis. After interpreting the results of illegitimate pollination, it is found that a small percentage of fruit set is obtained after intra-morph crossing. This indicates that the species shows a tendency towards intra-morph compatibility. Heterostylous species are usually selfand intra-morph incompatible and produce fruits only after legitimate (intermorph) pollination. However, selfand intra-morph compatibility was reported from both distylous (Ornduff 1976) and tristylous (Barrett 1985; Eckert \& Barrett 1994) species. Intra-morph compatibility accompanied by self-incompatibility is reported from tristylous Narcissus triandrus (Barrett et al. 1995) in Amaryllidaceae, from the distylous Anchusa hybrid (Dulberger, 1970), and from Anchusa officinalis (Philipp \& Schou, 1981) in Boraginaceae. In Rubiaceae, partial intramorph compatibility was reported from several self- incompatible distylous species like Psychotria nuda (Castro \& Araujo 2004), P. homalosperma (Watanabe et 
al. 2014) and Gaertnera vaginata (Pailler \& Thompson 1997) where fruit set was obtained after illegitimate pollination in one morph and no fruit set in the other one. Intramorph incompatibility may gradually decrease in the species and may become intramorph and selfcompatible in the future. The heterostylous species which are self-compatible were considered to be derived from self-incompatible ancestors (Baker 1966; Ganders 1979).

Fruit of $O$. caudata is a bi-valved capsule which dehisces along the dorsal surface. According to Deb \& Mondal (1997), many seeded dehiscent fruit of Ophiorrhiza which releases and disperses seeds is a primitive character while comparing to the few seeded indehiscent fruit. Flower-fruit ratio in the two morphs specifies that above $60 \%$ fruit set was obtained in natural conditions. Seed dispersal mechanism is splash or ballistic seed dispersal by rain drops in which the seeds are dispersed into the surroundings due to the pressure exerted by the rain drops falling in the loculicidal capsule. This kind of seed dispersal was reported in O. japonica in which the seeds are dispersed to a maximum distance of $95.0 \pm 6.2 \mathrm{~cm}$ (Nakanishi 2002). Nakanishi (2002) reported the same mechanism of seed dispersal in Sagina spp. (Caryophyllaceae), Sedum spp. (Crassulaceae), Gentiana spp. (Gentianaceae) and several members of Saxifragaceae and Scrophulariaceae. All these plants are herbaceous and splash rain dispersal might be an advantage for small plants because dispersal is not affected by plant height. Occasionally, in the absence of rain, the seeds of Ophiorrhiza sp. are dispersed by wind.

The minute seeds of Ophiorrhiza showed maximum seed germination within 2-4 weeks after the harvest. The seeds of Ophiorrhiza caudata showed more than 40-45\% germination in all the conditions, but only a few seedlings are establishing in the wild habitat. In natural conditions, most of the seeds are leached along with the rain water or buried in the muddy soil. The germinating seeds were also destroyed by heavy rain. There is increasing evidence that the events which occur during seedling establishment influences the distribution and abundance of adults in a plant community (Marks 1974; Platt 1975; Werner 1977; Rabinowitz 1978; Gross \& Werner 1982). Seeds leached out by the rain water which may germinate in a long distance apart which leads to habitat fragmentation.

\section{CONCLUSION}

Ophiorrhiza caudata is an endangered species endemic to the southern Western Ghats. It exhibits heterostyly, but shows some deviations from the typical characters of a heterostylous species. Its breeding system is self-incompatible but shows some degree of intra-morph compatibility, which has an evolutionary significance. Poor seedling establishment in wild conditions, habitat fragmentation, and anthropogenic activities are the major threats for the survival of the species. Only $25 \%$ of seedlings were established in the wild condition due to climatic problems. The seedlings were successfully established in Jawaharlal Nehru Tropical Botanic Garden and Research institute campus. Conservation of this rediscovered medicinal plant is of great significance in the present scenario. The self-incompatible heteromorphic species which is phasing environmental and other threats in its natural habitat is conserved in our campus. Both the morphs are protected, thereby promote cross pollination and further establishment of the species.

\section{REFERENCES}

Almeida, E.M. \& M.A.S. Alves (2000). Phenology of Psychotria nuda and $P$. brasiliensis (Rubiaceae) in an area of the Atlantic forest, Southeast of Brazil. Acta Botanica Brasilica 14: 335-346.

Baker, H.G. (1966). The evolution, functioning and breakdown of heteromorphic incompatibility systems. Evolution 20: 349-368

Barrett, S.C.H., Lloyd, D.G. \& J. Arroyo (1995). Stylar polymorphism and the evolution of heterostyly in Narcissus (Amaryllidaceae), pp. 336-376. In: Lloyd D.G. \& S.C.H. Barrett (eds.). Floral Biology: Studies on Floral Evolution in Animal Pollinated Plants. Chapman and Hall, New York.

Barrett, S.C.H. (1985). Floral trimorphism and monomorphism in continental and island populations of Eichornia paniculata (Spreng.) Solms. (Pontederiaceae). Botanical Journal of the Linnean Society 25: 41-60.

Castro, C.C. \& A.C. Araujo (2004). Distyly and sequential pollinators of Psychotria nuda (Rubiaceae) in the Atlantic rain forest, Brazil. Plant Systematics and Evolution 244: 131-139.

Consolaro, H., E.B. Silva \& P.E. Oliveira (2005). Floral variation and reproductive biology of Manettia cordifolia Mart. (Rubiaceae). Brazilian Journal of Botany 28: 85-94.

Consolaro, H., S.C.S. Silva \& P.E. Oliveira (2011). Breakdown of distyly and pin-monomorphism in Psychotria carthagenensis Jacq. (Rubiaceae). Plant Species Biology 26: 24-32.

Cruden, R.W. (1977). Pollen-ovule ratios: a conservative indicator of breeding system in flowering plants. Evolution 31: 32-46.

Dafni, A. (2007). Pollination Ecology. Field manual. Ashoka Trust of Research in Ecology and the Environment, Bangalore, $17 \mathrm{pp}$.

Darwin, C. (1877). The Different Forms of Flowers on Plants of the Same Species. John Murray, London, UK.

Deb, D.B. \& D.C. Mondal (1997). Taxonomic revision of the genus Ophiorrhiza L. (Rubiaceae) in Indian subcontinent. Bulletin of Botanical Survey of India 39: 99-100.

Dulberger, R. (1970). Floral dimorphism in Anchusa hybrida Ten. Israel Journal of Botany 19: 37-41. 
Eckert, C.G. \& S.C.H. Barrett (1994). Tristyly, self-compatibility and floral variation in Decodon verticillatus (Lythraceae). Biological Journal of the Linnean Society 53: 1-30.

Fonseca, N.G., Kumagai, A.F. \& O.H.H. Mielke (2006). Lepidopterans visiting the flowers of Stachytarpheta cayennensis (Rich.) Vahl (Verbenaceae) in Atlantic Forest remnants, Minas Gerais, Brasil. Revista Brasileira de Entomologia 50: 399-405.

Ganders, F.R. (1979). The biology of heterostyly. New Zealand Journal of Botany 17: 607-635

Gross, K.L. \& P.A. Werner (1982). Colonizing abilities of "biennial" plant species in relation to ground cover: implications for their distributions in a successional sere. Ecology 63: 921-931.

Joseph, G. \& J.P. Joseph, (2009). Rediscovery of Ophiorrhiza caudata (Rubiaceae) from the Western Ghats of Kerala. Rheedea 19: 45-46.

Koptur, S., Haber, W.A., Frankie, G.W. \& H.G. Baker (1988) Phenological studies of shrub and treelet species in tropical cloud forest of Costa Rica. Journal of Tropical Ecology 4: 323-346.

Li , A., X. Wu, D. Zhang \& S.C.H. Barrett (2010). Cryptic dioecy in Mussaenda pubescens (Rubiaceae): a species with stigma-height dimorphism. Annals of Botany 106: 521-531.

Lloyd, D.G. \& C.J. Webb (1992). The selection of heterostyly, pp. 179207. In: Barrett, S.C.H. (ed.). Evolution and Function of Heterostyly. Monographs on Theoretical and Applied Genetics. Springer-Verlag, Berlin.

Mabberley, D.J. (2008). The Plant-Book: A portable dictionary of plants, their classification and uses. $3^{\text {rd }}$ Edition. Cambridge University Press, Cambridge, UK, 603 pp.

Marks, P.L. (1974). The role of pin cherry (Prunus pennsylvanica L.) in the maintenance of stability in northern hardwood ecosystems. Ecological Monographs 44: 73-88.

Martin-Gajardo, I.S. \& L.P.C. Morellato (2003). Phenology of understorey Rubiaceae in the Atlantic forest, southeastern Brasil. Brazilian Journal of Botany 26: 299-309.

Naiki, A. \& M. Kato (1999). Pollination system and evolution of dioecy from distyly in Mussaenda parviflora (Rubiaceae). Plant Species Biology 14: 217-227.

Nakanishi, H. (2002). Splash seed dispersal by raindrops. Ecological Research 17: 663-671.

Ornduff, R. (1976). The reproductive system of Amsinckia grandiflora, a distylous species. Systematic Botany 1: 57-66.

Pailler, T. \& J.D. Thompson (1997). Distyly and variation in heteromorphic incompatibility in Gaertnera vaginata (Rubiaceae) endemic to La Reunion Island. American Journal of Botany 84: 315327
Philipp, M. \& O. Schou (1981). An unusual heteromorphic incompatibility system: distyly, self-incompatibility, pollen load and fecundity in Anchusa officinalis. New Phytologist 89: 693-703.

Platt, W.J. (1975). The colonization and formation of equilibrium plant communities on badger disturbances in a tall-grass prairie. Ecological Monographs 45: 285-305.

Rabinowitz, D. (1978). Early growth of mangrove seedlings in Panama and an hypothesis concerning the relationship of dispersal and zonation. Journal of Biogeography 5: 113-133.

Silva, N.A.P., Frizzas, M.R. \& C.M. Oliveira (2011). Seasonality in insect abundance in the "Cerrado" of Goias State, Brazil. Revista Brasileira de Entomologia 55: 79-87.

Stone, J.L. \& J.D. Thomson (1995). Pollen donation patterns in a tropical distylous shrub (Psychotria suerrensis; Rubiaceae). American Journal of Botany 82: 1390-1398.

Toler, T.R., Evans, E.W. \& V.J. Tepedino (2005). Pan-trapping for bees (Hymenoptera: Apiformes) in Utah's West Desert: the importance of color diversity. The pan -pacific entomologist 81(3/4): 103-113.

Uday, M.B. \& A.K. Kondapi (2010). Neurotoxic activity of a Topoisomerase-1 inhibitor, camptothecin, in cultured cerebellar granule neurons. Neuro Toxicology 31: 730-737.

Valois-Cuesta, H., Y.L. Diana \& Q. Zulay (2009). Reproductive ecology of Psychotria Poeppigiana (Rubiaceae): A comparative analysis between long-styled and short-styled plants. Ecotropicos 22: 1-12.

Watanabe, K., H. Kato \& S. Takashi (2014). Distyly and incompatibility in Psychotria homalosperma (Rubiaceae), an endemic plant of the oceanic Bonin (Ogasawara) Islands. Flora - Morphology, Distribution, Functional Ecology of Plants 209: 641-648.

Werner, P.A. (1977). Colonization success of a 'biennial' plant species: experimental field studies of species colonization and replacement. Ecology 58: 840-849.

Wolda, H. (1988). Insect seasonality: Why? Annual Review of Ecology and Systematics 19: 1-18.

Wolff, D. \& S. Liede-Schumann (2007). Evolution of flower morphology, pollen dimorphism, and nectar composition in Arcytophyllum, a distylous genus of Rubiaceae. Organisms Diversity and Evolution 7: 106-123.

Yamazaki, Y., H. Sudo, M. Yamazaki, N. Aimi \& K. Saito (2003). Camptothecin biosynthetic genes in hairy roots of Ophiorrhiza pumila: Cloning, characterization and differential expression in tissues and by stress compounds. Plant Cell Physiology 44: 395-403.

Wilio ZOOREACH 
Dr. John Noyes, Natural History Museum, London, UK

Dr. Albert G. Orr, Griffith University, Nathan, Australia

Dr. Sameer Padhye, Katholieke Universiteit Leuven, Belgium

Dr. Nancy van der Poorten, Toronto, Canada

Dr. Kareen Schnabel, NIWA, Wellington, New Zealand

Dr. R.M. Sharma, (Retd.) Scientist, Zoological Survey of India, Pune, India

Dr. Manju Siliwal, WILD, Coimbatore, Tamil Nadu, India

Dr. G.P. Sinha, Botanical Survey of India, Allahabad, India

Dr. K.A. Subramanian, Zoological Survey of India, New Alipore, Kolkata, India

Dr. P.M. Sureshan, Zoological Survey of India, Kozhikode, Kerala, India

Dr. R. Varatharajan, Manipur University, Imphal, Manipur, India

Dr. Eduard Vives, Museu de Ciències Naturals de Barcelona, Terrassa, Spain

Dr. James Young, Hong Kong Lepidopterists' Society, Hong Kong

Dr. R. Sundararaj, Institute of Wood Science \& Technology, Bengaluru, India

Dr. M. Nithyanandan, Environmental Department, La Ala Al Kuwait Real Estate. Co. K.S.C.,

Kuwait

Dr. Himender Bharti, Punjabi University, Punjab, India

Mr. Purnendu Roy, London, UK

Dr. Saito Motoki, The Butterfly Society of Japan, Tokyo, Japan

Dr. Sanjay Sondhi, TITLI TRUST, Kalpavriksh, Dehradun, India

Dr. Nguyen Thi Phuong Lien, Vietnam Academy of Science and Technology, Hanoi, Vietnam

Dr. Nitin Kulkarni, Tropical Research Institute, Jabalpur, India

Dr. Robin Wen Jiang Ngiam, National Parks Board, Singapore

Dr. Lional Monod, Natural History Museum of Geneva, Genève, Switzerland.

Dr. Asheesh Shivam, Nehru Gram Bharti University, Allahabad, India

Dr. Rosana Moreira da Rocha, Universidade Federal do Paraná, Curitiba, Brasi

Dr. Kurt R. Arnold, North Dakota State University, Saxony, Germany

Dr. James M. Carpenter, American Museum of Natural History, New York, USA

Dr. David M. Claborn, Missouri State University, Springfield, USA

Dr. Kareen Schnabel, Marine Biologist, Wellington, New Zealand

Dr. Amazonas Chagas Júnior, Universidade Federal de Mato Grosso, Cuiabá, Brasil

Mr. Monsoon Jyoti Gogoi, Assam University, Silchar, Assam, India

Dr. Heo Chong Chin, Universiti Teknologi MARA (UiTM), Selangor, Malaysia

Dr. R.J. Shiel, University of Adelaide, SA 5005, Australia

Dr. Siddharth Kulkarni, The George Washington University, Washington, USA

Dr. Priyadarsanan Dharma Rajan, ATREE, Bengaluru, India

Dr. Phil Alderslade, CSIRO Marine And Atmospheric Research, Hobart, Australia

Dr. John E.N. Veron, Coral Reef Research, Townsville, Australia

Dr. Daniel Whitmore, State Museum of Natural History Stuttgart, Rosenstein, Germany.

Dr. Yu-Feng Hsu, National Taiwan Normal University, Taipei City, Taiwan

Dr. Keith V. Wolfe, Antioch, California, USA

Dr. Siddharth Kulkarni, The Hormiga Lab, The George Washington University, Washington,

D.C., USA

Dr. Tomas Ditrich, Faculty of Education, University of South Bohemia in Ceske

Budejovice, Czech Republic

Dr. Mihaly Foldvari, Natural History Museum, University of Oslo, Norway

Dr. V.P. Uniyal, Wildlife Institute of India, Dehradun, Uttarakhand 248001, India

Dr. John T.D. Caleb, Zoological Survey of India, Kolkata, West Bengal, India

Dr. Priyadarsanan Dharma Rajan, Ashoka Trust for Research in Ecology and the Environment

(ATREE), Royal Enclave, Bangalore, Karnataka, India

\section{Fishes}

Dr. Neelesh Dahanukar, IISER, Pune, Maharashtra, India

Dr. Topiltzin Contreras MacBeath, Universidad Autónoma del estado de Morelos, México

Dr. Heok Hee Ng, National University of Singapore, Science Drive, Singapore

Dr. Rajeev Raghavan, St. Albert's College, Kochi, Kerala, India

Dr. Robert D. Sluka, Chiltern Gateway Project, A Rocha UK, Southall, Middlesex, UK

Dr. E. Vivekanandan, Central Marine Fisheries Research Institute, Chennai, India

Dr. Davor Zanella, University of Zagreb, Zagreb, Croatia

Dr. A. Biju Kumar, University of Kerala, Thiruvananthapuram, Kerala, India

Dr. Akhilesh K.V., ICAR-Central Marine Fisheries Research Institute, Mumbai Research

Centre, Mumbai, Maharashtra, India

Dr. J.A. Johnson, Wildlife Institute of India, Dehradun, Uttarakhand, India

Amphibians

Dr. Sushil K. Dutta, Indian Institute of Science, Bengaluru, Karnataka, India

Dr. Annemarie Ohler, Muséum national d'Histoire naturelle, Paris, France

\section{Reptiles}

Dr. Gernot Vogel, Heidelberg, Germany

Dr. Raju Vyas, Vadodara, Gujarat, India

Dr. Pritpal S. Soorae, Environment Agency, Abu Dubai, UAE.

Prof. Dr. Wayne J. Fuller, Near East University, Mersin, Turkey

Prof. Chandrashekher U. Rivonker, Goa University, Taleigao Plateau, Goa. India

Dr. S.R. Ganesh, Chennai Snake Park, Chennai, Tamil Nadu, India

Dr. Himansu Sekhar Das, Terrestrial \& Marine Biodiversity, Abu Dhabi, UAE
Birds

Dr. Hem Sagar Baral, Charles Sturt University, NSW Australia

Dr. Chris Bowden, Royal Society for the Protection of Birds, Sandy, UK

Dr. Priya Davidar, Pondicherry University, Kalapet, Puducherry, India

Dr. J.W. Duckworth, IUCN SSC, Bath, UK

Dr. Rajah Jayapal, SACON, Coimbatore, Tamil Nadu, India

Dr. Rajiv S. Kalsi, M.L.N. College, Yamuna Nagar, Haryana, India

Dr. V. Santharam, Rishi Valley Education Centre, Chittoor Dt., Andhra Pradesh, India

Dr. S. Balachandran, Bombay Natural History Society, Mumbai, India

Mr. J. Praveen, Bengaluru, India

Dr. C. Srinivasulu, Osmania University, Hyderabad, India

Dr. K.S. Gopi Sundar, International Crane Foundation, Baraboo, USA

Dr. Gombobaatar Sundev, Professor of Ornithology, Ulaanbaatar, Mongolia

Prof. Reuven Yosef, International Birding \& Research Centre, Eilat, Israel

Dr. Taej Mundkur, Wetlands International, Wageningen, The Netherlands

Dr. Carol Inskipp, Bishop Auckland Co., Durham, UK

Dr. Tim Inskipp, Bishop Auckland Co, Durham, UK

Dr. V. Gokula, National College, Tiruchirappalli, Tamil Nadu, India

Dr. Arkady Lelej, Russian Academy of Sciences, Vladivostok, Russia

Dr. Simon Dowell, Science Director, Chester Zoo, UK

Dr. Mário Gabriel Santiago dos Santos, Universidade de Trás-os-Montes e Alto Douro,

Quinta de Prados, Vila Real, Portugal

Dr. Grant Connette, Smithsonian Institution, Royal, VA, USA

Dr. M. Zafar-ul Islam, Prince Saud Al Faisal Wildlife Research Center, Taif, Saudi Arabia

Mammals

Dr. Giovanni Amori, CNR - Institute of Ecosystem Studies, Rome, Italy

Dr. Anwaruddin Chowdhury, Guwahati, India

Dr. David Mallon, Zoological Society of London, UK

Dr. Shomita Mukherjee, SACON, Coimbatore, Tamil Nadu, India

Dr. Angie Appel, Wild Cat Network, Germany

Dr. P.O. Nameer, Kerala Agricultural University, Thrissur, Kerala, India

Dr. Ian Redmond, UNEP Convention on Migratory Species, Lansdown, UK

Dr. Heidi S. Riddle, Riddle's Elephant and Wildlife Sanctuary, Arkansas, USA

Dr. Karin Schwartz, George Mason University, Fairfax, Virginia.

Dr. Lala A.K. Singh, Bhubaneswar, Orissa, India

Dr. Mewa Singh, Mysore University, Mysore, India

Dr. Paul Racey, University of Exeter, Devon, UK

Dr. Honnavalli N. Kumara, SACON, Anaikatty P.O., Coimbatore, Tamil Nadu, India

Dr. Nishith Dharaiya, HNG University, Patan, Gujarat, India

Dr. Spartaco Gippoliti, Socio Onorario Società Italiana per la Storia della Fauna "Giuseppe

Altobello", Rome, Italy

Dr. Justus Joshua, Green Future Foundation, Tiruchirapalli, Tamil Nadu, India

Dr. H. Raghuram, The American College, Madurai, Tamil Nadu, India

Dr. Paul Bates, Harison Institute, Kent, UK

Dr. Jim Sanderson, Small Wild Cat Conservation Foundation, Hartford, USA

Dr. Dan Challender, University of Kent, Canterbury, UK

Dr. David Mallon, Manchester Metropolitan University, Derbyshire, UK

Dr. Brian L. Cypher, California State University-Stanislaus, Bakersfield, CA

Dr. S.S. Talmale, Zoological Survey of India, Pune, Maharashtra, India

Prof. Karan Bahadur Shah, Budhanilakantha Municipality, Kathmandu, Nepal

Dr. Susan Cheyne, Borneo Nature Foundation International, Palangkaraja, Indonesia

Dr. Hemanta Kafley, Wildlife Sciences, Tarleton State University, Texas, USA

\section{Other Disciplines}

Dr. Aniruddha Belsare, Columbia MO 65203, USA (Veterinary)

Dr. Mandar S. Paingankar, University of Pune, Pune, Maharashtra, India (Molecular)

Dr. Jack Tordoff, Critical Ecosystem Partnership Fund, Arlington, USA (Communities)

Dr. Ulrike Streicher, University of Oregon, Eugene, USA (Veterinary)

Dr. Hari Balasubramanian, EcoAdvisors, Nova Scotia, Canada (Communities)

Dr. Rayanna Hellem Santos Bezerra, Universidade Federal de Sergipe, São Cristóvão, Brazil

Dr. Jamie R. Wood, Landcare Research, Canterbury, New Zealand

Dr. Wendy Collinson-Jonker, Endangered Wildlife Trust, Gauteng, South Africa

Dr. Rajeshkumar G. Jani, Anand Agricultural University, Anand, Gujarat, India

Dr. O.N. Tiwari, Senior Scientist, ICAR-Indian Agricultural Research Institute (IARI), New

Delhi, India

Dr. L.D. Singla, Guru Angad Dev Veterinary and Animal Sciences University, Ludhiana, India

Dr. Rupika S. Rajakaruna, University of Peradeniya, Peradeniya, Sri Lanka

Dr. Bahar Baviskar, Wild-CER, Nagpur, Maharashtra 440013, India

Reviewers 2018-2020

Due to pausity of space, the list of reviewers for $2018-2020$ is available online.

The opinions expressed by the authors do not reflect the views of the Journal of Threatened Taxa, Wildlife Information Liaison Development Society, Zoo Outreach Organization, or any of the partners. The journal, the publisher, the host, and the partners are not responsible for the accuracy of the political boundaries shown in the maps by the authors.

Journal of Threatened Taxa is indexed/abstracted in Bibliography of Systematic Mycology, Biological Abstracts, BIOSIS Previews, CAB Abstracts, EBSCO, Google Scholar, Index Copernicus, Index Fungorum, JournalSeek, National Academy of Agricultural Sciences, NewJour, OCLC WorldCat, SCOPUS, Stanford University Libraries, Virtual Library of Biology, Zoological Records.

NAAS rating (India) 5.64
Print copies of the Journal are available at cost. Write to:

The Managing Editor, JoTT,

c/o Wildlife Information Liaison Development Society,

No. 12, Thiruvannamalai Nagar, Saravanampatti - Kalapatti Road,

Saravanampatti, Coimbatore, Tamil Nadu 641035, India

ravi@threatenedtaxa.org 


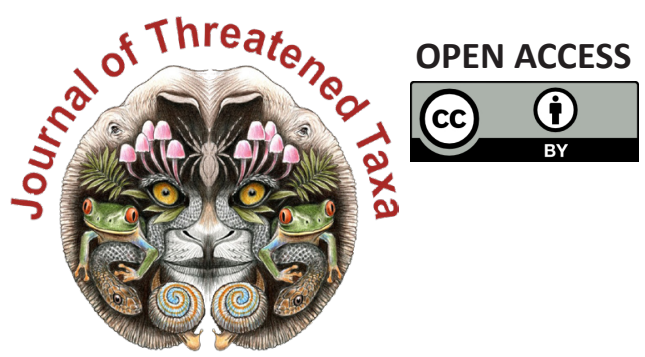

www.threatenedtaxa.org

The Journal of Threatened Taxa (JoTT) is dedicated to building evidence for conservation globally by publishing peer-reviewed articles online every month at a reasonably rapid rate at www.threatenedtaxa.org. All articles published in JoTT are registered under Creative Commons Attribution 4.0 International License unless otherwise mentioned. JoTT allows allows unrestricted use, reproduction, and distribution of articles in any medium by providing adequate credit to the author(s) and the source of publication.

ISSN 0974-7907 (Online) I ISSN $0974-7893$ (Print)

\section{November 2021 | Vol. 13 | No. 13 | Pages: 19887-20142 \\ Date of Publication: 26 November 2021 (Online \& Print) DOI: 10.11609/jott.2021.13.13.19887-20142}

\section{Article}

An inventory of geometrid moths (Lepidoptera: Geometroidea: Geometridae) of KalakadMundanthurai Tiger Reserve, India

- Geetha Iyer, Dieter Stüning \& Sanjay Sondhi, Pp. 19887-19920

\section{Communications}

Roadkills of Lowland Tapir Tapirus terrestris (Mammalia: Perissodactyla: Tapiridae) in one of its last refuges in the Atlantic Forest

- Aureo Banhos, Andressa Gatti, Marcelo Renan de Deus Santos, Leonardo Merçon,

Ilka Westermeyer, Natália Carneiro Ardente, Luis Francisco Oliveira Pereira Gonzaga, Lucas Mendes Barreto, Lucas Damásio, Tomas Lima Rocha, Vitor Roberto Schettino, Renata Valls, Helena Godoy Bergallo, Marcos Vinicius Freitas Silva, Athelson Stefanon Bittencourt, Danielle de Oliveira Moreira \& Ana Carolina Srbek-Araujo, Pp. 19921-19929

Scientific contributions and learning experiences of citizen volunteers with a small cat project in Sanjay Gandhi National Park, Mumbai, India

- Shomita Mukherjee, R. Nandini, P.V. Karunakaran \& Nayan Khanolkar, Pp. 19930-19936

Seasonal food preferences and group activity pattern of Blackbuck Antilope cervicapra (L., 1758) (Mammalia: Cetartiodactyla: Bovidae) in a semi-arid region of western Haryana, India

- Vikram Delu, Dharambir Singh, Sumit Dookia, Priya \& Kiran, Pp. 19937-19947

Studies on the habitats of Grey Francolin Francolinus pondicerianus (J.F. Gmelin, 1789) (Galliformes: Phasianidae) in northern districts of Tamil Nadu, India

- M. Pandian, Pp. 19948-19955

Recovery of vulture population in roosting and scavenging areas of Bastar and Bijapur, Chhattisgarh, India

- Sushil Kumar Dutta, Muntaz Khan, P.R.S. Nagi, Santosh Durgam \& Surabhi Dutta, Pp. 19956-19963

A geographical assessment of Chariganga and Arpara Beel (wetlands) of Nadia, West Bengal as a habitat of wetland birds

- Mehedi Hasan Mandal, Arindam Roy \& Giyasuddin Siddique, Pp. 19964-19975

Phenotypic plasticity in Barilius vagra (Hamilton, 1822) (Teleostei: Danionidae) from two geographically distinct river basins of Indian Himalaya

- Sumit Kumar, Sharali Sharma \& Deepak Singh, Pp. 19976-19984

Taxonomic notes, a new species, and a key to Indian species of the click beetle genus Cryptalaus Ôhira, 1967 (Coleoptera: Elateridae: Agrypninae)

- Harshad Parekar \& Amol Patwardhan, Pp. 19985-19999

Niche overlap of benthic macrofauna in a tropical estuary: diurnal variation

- Mário Herculano de Oliveira, Lidiane Gomes de Lima, Caroline Stefani da Silva Lima, Jéssica de Oliveira Lima Gomes, Franciely Ferreira Paiva, Graciele de Barros, Carlinda Railly Medeiros \& Joseline Molozzi, Pp. 20000-20010

Diversity of aquatic insects and biomonitoring of water quality in the upper Ganga River, a Ramsar site: a preliminary assessment

- Kritish De, Arkojyoti Sarkar, Kritika Singh, Virendra Prasad Uniyal, Jeyaraj Antony Johnson \& Syed Ainul Hussain, Pp. 20011-20018

Patterns of forest cover loss in the terrestrial Key Biodiversity Areas in the Philippines: critical habitat conservation priorities

- Bernard Peter O. Daipan, Pp. 20019-20032

The woody flora of Shettihalli Wildlife Sanctuary, central Western Ghats of Karnataka, India - A checklist

- Kanda Naveen Babu, Kurian Ayushi, Vincy K. Wilson, Narayanan Ayyappan \&

Narayanaswamy Parthasarathy, Pp. 20033-20055

Reproductive biology of Ophiorrhiza caudata C.E.C.Fisch. (Rubiaceae), an endemic and endangered creeping perennial herb of the Western Ghats, India

- Maria Theresa, Appukuttan Kamalabai Sreekala \& Jayalakshmi Mohanlal, Pp. 20056-20065
Short Communications

Successful rescue, medical management, rehabilitation, and translocation of a Red Panda Ailurus fulgens (Mammalia: Carnivora: Ailuridae) in Arunachal Pradesh, India - Jahan Ahmed, Sorang Tadap, Millo Tasser, Koj Rinya, Nekibuddin Ahmed \& Sunil Kyarong, Pp. 20066-20071

A rare photographic record of Eurasian Otter Lutra lutra with a note on its habitat from the Bhagirathi Basin, western Himalaya, India

- Ranjana Pal, Aashna Sharma, Vineet Kumar Dubey, Tapajit Bhattacharya, Jeyaraj Antony Johnson, Kuppusamy Sivakumar \& Sambandam Sathyakumar, Pp. 20072-20077

The first record of Medog Gliding Frog Rhacophorus translineatus Wu, 1977 (Anura: Rhacophoridae) from Chhukha District, Bhutan

- Sonam Lhendup \& Bal Krishna Koirala, Pp. 20078-20083

First record of a freshwater crab, Maydelliathelphusa masoniana (Henderson, 1893) (Decapoda: Brachyura: Gecarcinucidae) from West Bengal, India

- Ram Krishna Das, Pp. 20084-20089

Butterflies of Amrabad Tiger Reserve, Telangana, India

- Deepa Jaiswal, B. Bharath, M. Karuthapandi, Shrikant Jadhav, S. Prabakaran \& S. Rehanuma Sulthana, Pp. 20090-20097

An enumeration of the flowering plants of Kyongnosla Alpine Sanctuary in eastern Sikkim, India

- Sudhansu Sekhar Dash, Subhajit Lahiri \& Ashiho Asoshii Mao, Pp. 20098-20117

A new record of psychrotrophic Paecilomyces formosus (Eurotiales: Ascomycota) from India: morphological and molecular characterization

- Skarma Nonzom \& Geeta Sumbali, Pp. 20118-20123

Notes

Study on incidence and pathology of gastrointestinal parasitic infections in Nilgai Boselaphus tragocamelus in Hisar, Haryana, India

- Maneesh Sharma, B.L. Jangir, D. Lather, G.A. Chandratre, V. Nehra, K.K. Jakhar \& G. Narang, Pp. 20124-20127

An unusual vocalization of Brown Hawk-Owl Ninox scutulata (Raffles, 1822) (Aves:

Strigiformes: Strigidae) recorded from Kerala, India

- Riju P. Nair \& Shine Raj Tholkudiyil, Pp. 20128-20129

New distribution data on the genus Maripanthus Maddison, 2020 (Araneae: Salticidae) from southern India

- A. Asima, John T.D. Caleb, Dhruv A. Prajapati \& G. Prasad, Pp. 20130-20132

On the IUCN status of Boesenbergia albolutea and B. rubrolutea (Zingiberaceae) and typification of $B$. rubrolutea

- K. Aishwarya \& M. Sabu, Pp. 20133-20135

New records of mass seeding Cephalostachyum latifolium Munro (Poaceae) along the midelevation broadleaved forest of Sarpang district, Bhutan

- Jigme Tenzin, Sangay Nidup \& Dago Dorji, Pp. 20136-20139

Response

If habitat heterogeneity is effective for conservation of butterflies in urban landscapes of Delhi, India?' Unethical publication based on data manipulation

- Sanjay Keshari Das \& Rita Singh, Pp. 20140-20142

Publisher \& Host
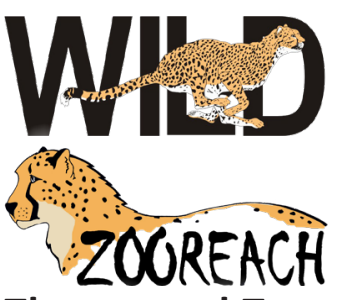

Threatened Taxa 